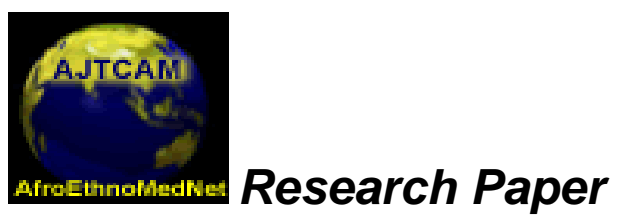

$$
\begin{gathered}
\text { Afr. J. Traditional, } \\
\text { Complementary and } \\
\text { Alternative Medicines } \\
\text { www.africanethnomedicines.net }
\end{gathered}
$$

ISSN 0189-6016@2008

\title{
PHYTO-CONSTITUENTS AND ANTI-OXIDANT ACTIVITY OF THE PULP OF SNAKE TOMATO (TRICHOSANTHES CUCUMERINA L.)
}

\author{
O. C. Adebooye*
}

\begin{abstract}
Alexander von Humboldt Research Fellow, Institut für Gartenbauwissenschaft, University of Bonn, Auf dem Hügel 6, D 53121 Bonn, Germany. *Permanent Address: Department of Plant Science, Obafemi Awolowo University, Ile-Ife, Nigeria.

Email: adebooye@uni-bonn.de
\end{abstract}

\begin{abstract}
The phyto-constituents and antioxidant activity of the fruit pulp of Trichosanthes cucumerina L. have not been reported in literature and were therefore studied. Two identified morphotypes of this plant (Morphotype I [V1] having long fruit with deep green background and white stripes; and Morphotype II [V2] having light green coloured long fruit) were used for the studies. The dry matter contents of the pulp of the V1 and V2 were 10.9 and $9.6 \mathrm{~g} / 100 \mathrm{~g}$ fresh weight (FW), while the ascorbic acid contents were 25.7 and $24.8 \mathrm{mg} / 100 \mathrm{~g}$ fresh weight (FW), and lycopene contents were 18.0 and $16.1 \mathrm{mg} / 100 \mathrm{~g} \mathrm{FW}$, respectively. The total phenolics, total flavonoids and total ferric reducing antioxidant power (FRAP) of V2 were significantly higher $(\mathrm{P}<0.05)$ than that of $\mathrm{V} 1$ by $46.8 \%, 78.0 \%$ and $26.2 \%$, respectively. Bulk of the carotenoids is made up of lutein in the concentration of 15.6 and $18.4 \mathrm{mg} / 100 \mathrm{~g} \mathrm{FW}$, for V1 and V2, respectively. The $\alpha$-carotene contents were 10.3 and $10.7 \mathrm{mg} / 100 \mathrm{~g} \mathrm{FW}$ while the $\beta$-carotene contents were 2.4 and $2.8 \mathrm{mg} / 100 \mathrm{~g} \mathrm{FW}$ for V1 andV2, respectively. It is concluded from the results of this study that the two morphotypes of $T$. cucumerina possess valuable nutraceutical properties that can qualify them as viable substitute to the Solanaceous tomato.
\end{abstract}

Key words: Trichosanthes cucumerina L, phenolics, flavonoids, antioxidant power

\section{Introduction}

The Food and Agricultural Organization of the United Nations (FAO)(1998) reported that countries of West and Central Africa sub-regions have a large number of under-utilized indigenous edible plant species that are important to the livelihoods of local population. Numerous scientific studies have shown the importance of indigenous edible plants in the nutrition of the rural human population in Africa (Chweya, 1996; Abukutsa-Onyago, 2003; Adebooye, 1996; Adebooye et al., 2001). All over Africa, these traditional food plants have been major sources of nutrients for rural dwellers that cannot pay for milk, egg and milk (Adebooye, 1996). One of such high premium indigenous food plant is Trichosanthes cucumerina L. Adebooye et al. (2006) reported that Trichosanthes cucumerina L., a member of the Cucurbitaceae, also locally known as Snake Tomato, is utilized as a substitute to the Solanaceous tomato (Lycopersicon esculentum (L.) Mill.) due to its sweet tasting, aromatic, and deep red endocarp pulp when fully ripe and that the fruit pulp does not go sour as quickly as paste of L. esculentum. These good qualities have made this plant a substitute to the Solanaceous tomato especially during the off-season when prices of Solanaceous tomato are very high, suggesting that consumption maybe related to income level. The pulp is a good source of ascorbic acid (23.1-23.3 mg/100 g), which is far higher than that of the popular Solanaceous tomato varieties in Nigeria, thereby suggesting its possible use for paste and puree (Adebooye et al., 2005). Fruits and vegetables are good sources of natural antioxidants for the human diet, containing many different antioxidant 
components which provide protection against harmful free radicals and have been strongly associated with reduced risk of chronic diseases, such as cardiovascular disease, cancer, diabetes, Alzheimer's disease, cataracts and agerelated functional decline in addition to other health benefits (Cao et al., 1996; Wang et al., 1996; Velioglu et al.,1998; Cohen et al., 2000; Liu et al., 2000; Knekt et al., 2002; Sweeney et al., 2002; Amin et al., 2004; Sahlin et al., 2004). These positive effects are believed to be attributable to the antioxidants, particularly the carotenoids, flavonoids, lycopene, phenolics and B-carotene (Lavelli et al., 2000; Amin et al., 2004; Zhang and Hamauzu, 2004). Despite the good qualities of the fruit of T. cucumerina and its wide consumption by the poor rural population in Nigeria, research has not attempted studying the activity and components of antioxidant of this plant. This study was therefore designed to study the activity and components of antioxidant in two Nigerian indigenous morphotypes of T. cucumerina that had earlier been reported in literature (Adebooye et al., 2005; Oloyede and Adebooye, 2005; Adebooye and Oloyede, 2006).

\section{Materials and Methods Plant material}

Fully ripe fruit pulp of two morphotypes of T. cucumerina that were produced at the Teaching and Research Farm, Obafemi Awolowo University, Ile-Ife, Nigeria were used for this study. Morphotype I [V1] have long fruit with deep green background and white stripes at unripe stage while Morphotype II [V2] have light green coloured long fruit when at unripe stage. The fruits were split open and the pulp was extracted. The pulp for each morphotype was freeze-dried and stored until required for analyses.

The following determinations were carried out:

\section{Ascorbic acid determination}

For ascorbic acid determination the method described by Sahlin et al. (2004) was used. Ascorbic acid was measured by titration with phenolindo-2, 6- dichlorophenol (DPIP). The powder $(0.2 \mathrm{~g})$ was mixed with $40 \mathrm{~mL}$ of a buffer solution made up of $1 \mathrm{~g} / \mathrm{L}$ oxalic acid and $4 \mathrm{~g} / \mathrm{L}$ sodium acetate anhydrous. This was titrated against a solution containing $295 \mathrm{mg} / \mathrm{L}$ DPIP and $100 \mathrm{mg} / \mathrm{L}$ sodium bicarbonate. The results were expressed as $\mathrm{mg} / 100 \mathrm{~g} \mathrm{FW}$ and DM.

\section{Total phenolics determination}

Total phenolic was determined by employing Folin-Ciocalteu reaction, as determined by Zhi and Howard (2005). About $2 \mathrm{~g}$ sample was added to $25 \mathrm{~mL}$ double distilled water $(\mathrm{pH} 7.0)$ at $100{ }^{\circ} \mathrm{C}$. The sample was homogenized with a dismembrator followed by the transfer of the homogenate. The homogenate was transferred to a rotary shaker (Remi Instruments, India) for $6 \mathrm{~h}$ to ensure full extraction. The homogenate was thereafter filtered, the filtrate was made up to $50 \mathrm{~mL}$ and then centrifuged at $3800 \mathrm{rpm}$ for $10 \mathrm{~min}$. The supernatant was used for total phenolics determination. Two hundred microliter of supernatant was added to $1 \mathrm{~mL}$ of 1:10 diluted Folin Ciocalteu reagent. After $4 \mathrm{~min}, 800$ microliter of sodium carbonate $\left(75 \mathrm{~g} \mathrm{~L}^{-1}\right)$ was added. After $2 \mathrm{~h}$ of incubation at room temperature, the absorbance at $765 \mathrm{~nm}$ was measured. Gallic acid $\left(0-100 \mathrm{mg} \mathrm{L}^{-1}\right)$ was used for calibration of a standard curve. The results were expressed as gallic acid equivalents (GAE) per $100 \mathrm{~g} \mathrm{FW}$ and DM.

\section{Total tannins determination}

The method described by Pearson (1976), with slight modification, was used for the determination of tannin content of samples. Extraction of tannin was achieved by grinding $2 \mathrm{~g}$ of freeze-dried sample in $50 \mathrm{~mL}$ distilled water in pestle and mortar. The homogenate was transferred to a rotary shaker (Remi Instruments) for $12 \mathrm{~h}$. Thereafter, the homogenate was filtered and the filtrate (extract) made up to $50 \mathrm{~mL}$. One millilitre of the extract of standard tannic acid $\left(0.01 \mathrm{~g} \mathrm{~L}^{-1}\right.$ tannic acid) was measured into different test tubes and $1 \mathrm{~mL}$ of Folin-Denis reagent was added to each test tube followed by $2.5 \mathrm{~mL}$ of saturated sodium carbonate solution. The solutions were made up to $10 \mathrm{~mL}$ mark with distilled water and shaken to mix properly. Thereafter, reaction mixtures were incubated at room temperature (approximately $30{ }^{\circ} \mathrm{C}$ ) for $30 \mathrm{~min}$. The absorbance was measured against the reagent blank (containing $1 \mathrm{~mL}$ distilled water in place of extract or standard tannic acid solution) in a UV-Visible spectrophotometer Model UV 1601 version 2.40 (Shimadzu) at $760 \mathrm{~nm}$.

\section{Total flavonoids determination}


The aluminium chloride colorimetric assay was used for total flavonoids determination, as described by Marinova et al. (2005). Extraction of flavonoids was achieved by homogenizing $2 \mathrm{~g}$ of the pulp in $50 \mathrm{~mL}$ distilled water in pestle and mortar. The homogenate was transferred to a rotary shaker (Remi Instruments) for $12 \mathrm{~h}$. The suspension was filtered and the filtrate (extract) made up to $50 \mathrm{~mL}$. Precisely, $1 \mathrm{~mL}$ of extracts or standard solution of catechin $\left(20,40,60,80\right.$ and $\left.100 \mathrm{mg} \mathrm{L}^{-1}\right)$ was added to test tubes containing $4 \mathrm{~mL}$ of double-distilled water. To the mixture was added $0.3 \mathrm{~mL} \mathrm{5 \%} \mathrm{NaNO2}$. After $5 \mathrm{~min}, 0.3 \mathrm{~mL} \mathrm{10 \% (w/v)} \mathrm{AlCl3} \mathrm{was} \mathrm{added,} \mathrm{then} 2 \mathrm{~mL}$ of $1 \mathrm{M} \mathrm{NaOH}$ and the total volume was made up to $10 \mathrm{~mL}$ with double-distilled water. The solution was mixed thoroughly and the absorbance of both the samples, blank and standard, were read at $510 \mathrm{~nm}$ using UV-Visible spectrophotometer Model UV 1601 version 2.40 (Shimadzu). Total flavonoids content was expressed as mg catechin equivalents (CE per $100 \mathrm{~g}$ FW and DM).

\section{Lycopene determination}

Lycopene was extracted in the dark from 100mg of the sample powder using $5 \mathrm{~mL}$ of heptane for $10 \mathrm{~min}$ at $45{ }^{\circ} \mathrm{C}$, then for a further $30 \mathrm{~min}$ on a rotary mixer at $5-7{ }^{\circ} \mathrm{C}$ and then filtered (Sahlin et al., 2004). Further $3 \mathrm{~mL}$ heptane was added to the residues, mixed vigorously for $1 \mathrm{~min}$ and the supernatant was pooled with the first. The extraction was again repeated with $3 \mathrm{~mL}$ of heptane. The absorbance of the combined heptane extract was measured at $470 \mathrm{~nm}$ and the concentration of lycopene was calculated using molar molar extinction coefficient of $3450 \mathrm{M}^{-1} \mathrm{~cm}^{-1}$ (Van het Hof et al. 2000).

\section{Carotenoids components determination}

Carotenoids were analyzed according to the methods described by Zhang and Hamauzu (2004). Briefly, 15 $\mathrm{g}$ of powdered samples were homogenized with $10 \mathrm{ml}$ acetone at $-20{ }^{\circ} \mathrm{C}$. The homogenate was filtered with four layers of cheesecloth. The residue was treated with acetone $\left(-20^{\circ} \mathrm{C}\right)$ for three successive extractions until the green colour could no longer be visually detected in the extract and residue. The filtrate was combined and centrifuged at 4000rpm for $10 \mathrm{~min}$. The supernatant was collected and then filtered through a $0.45 \mu \mathrm{m}$ Advantec filter pore for HPLC analysis. Samples were separated on a Luna $5 \mu \mathrm{C} 18$ column $(150 \times 4.60 \mathrm{~mm}$ from Phenomenex $)$ at $40{ }^{\circ} \mathrm{C}$ by an HPLC (SHIMADZU LC-VP Liquid Chromatograph equipped with a SPD M10Avp photodiode array detector). The mobile phase consisted of acetonitrile : water (9:1, solvent A) and ethyl acetate (solvent B). The flow rate was $1.0 \mathrm{ml} / \mathrm{min}$. The following gradient elution was used for separation: $0 \% \mathrm{~B}$ at $0 \mathrm{~min}, 50 \% \mathrm{~B}$ at $20 \mathrm{~min}$, and $50 \% \mathrm{~B}$ at $35 \mathrm{~min}$. Samples were detected at $450 \mathrm{~nm}$. Identification of carotenoids was tentatively achieved by their retention times and UV spectra, recorded with a SHIMADZU SPD-M10Avp photodiode array detector, in comparison with authentic $\beta$-carotene and carotenoids, identified according to Howard et al. (2000) and Mizda et al. (2002). The contents of carotenoids were expressed as milligramme per $100 \mathrm{~g} \mathrm{FW}$ and DM.

\section{Ferric-reducing antioxidant power (FRAP) assay}

The ferric-reducing antioxidant power (FRAP) assay was carried out in triplicate according to the method of Benzie and Strain (1996). The FRAP reagent was prepared by mixing acetate buffer $\mathrm{pH}$ 3.6, Solution X and 20 $\mathrm{mM}$ iron (III) chloride solution in proportions 10:1:1 (v/v/v), respectively. Solution X was prepared by mixing 10 $\mathrm{mM}$ 2,4,6-Tri(2-pyridyl)-s-triazine (TPTZ) and $40 \mathrm{mM} \mathrm{HCl}$. Fresh FRAP reagent was used for the analyses and was warmed to $37^{\circ} \mathrm{C}$ prior to use. Fifty microliter of sample (2 g) (extracted in $20 \%(\mathrm{v} / \mathrm{v})$ acetone) were added to $1.5 \mathrm{~mL}$ of the FRAP reagent. The absorbance was measured at $593 \mathrm{~nm}$ after 4 min incubation. The standard curve was constructed using Iron (II) sulphate solution (100-200 $\mu \mathrm{M}$ ) and the results were expressed as mmol Fe (II)/100g FW and DM. 
Table 1: Dry matter, lycopene, ascorbic acid, total phenolics, tannins, total flavonoids and ferric reducing antioxidant power (FRAP) of two morphotypes of T. cucumerina $\mathrm{L}^{+}$

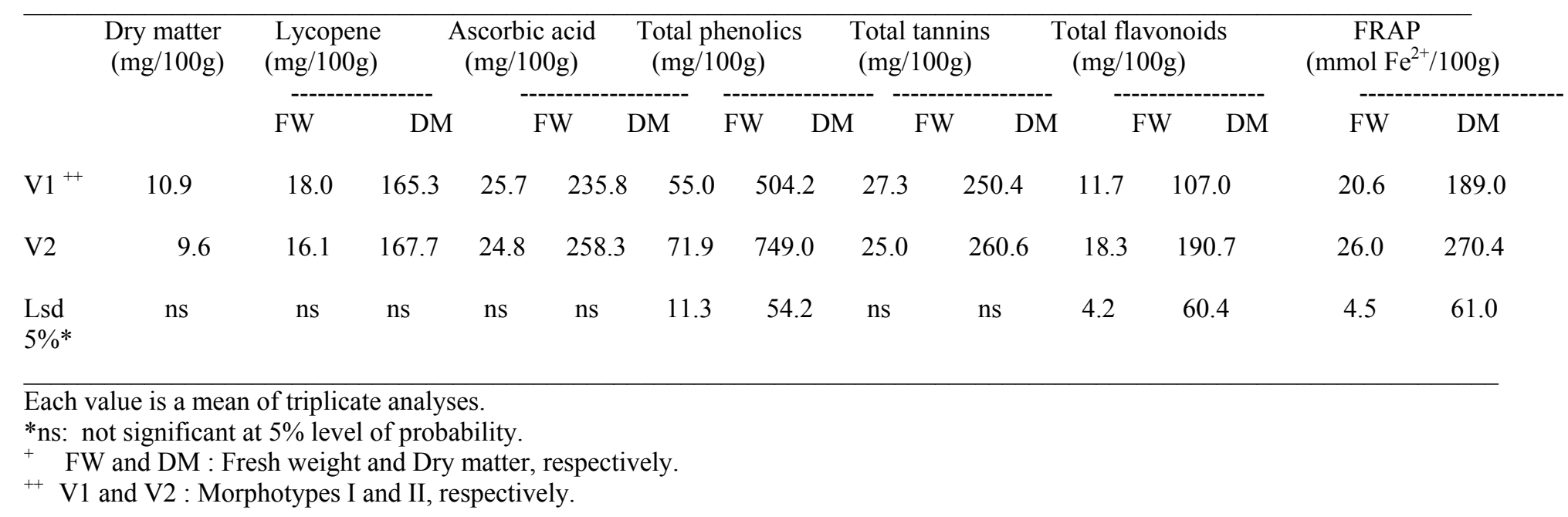

Table 2: Components of carotenoids of two morphotypes of T. cucumerina L. ${ }^{+}$

\begin{tabular}{|c|c|c|c|c|c|c|}
\hline & \multirow{2}{*}{$\begin{array}{r}\text { Lutein } \\
\text { FW }\end{array}$} & \multirow{2}{*}{$\begin{array}{c}(\mathrm{mg} / 100 \mathrm{~g}) \\
\mathrm{DM}\end{array}$} & \multicolumn{2}{|c|}{$\alpha$-carotene $(\mathrm{mg} / 100 \mathrm{~g})$} & \multicolumn{2}{|c|}{$\beta$-carotene $(\mathrm{mg} / 100 \mathrm{~g})$} \\
\hline & & & FW & $\mathrm{DM}$ & FW & $\mathrm{DM}$ \\
\hline V1 & 15.6 & 143.1 & 10.3 & 94.5 & 2.4 & 22.0 \\
\hline $\mathrm{V} 2$ & 18.4 & 191.7 & 10.7 & 101.5 & 2.8 & 29.2 \\
\hline $\operatorname{Lsd} 5 \% *$ & 1.2 & 20.1 & ns & ns & ns & ns \\
\hline
\end{tabular}

Each value is a mean of triplicate analyses. *ns: not significant at $5 \%$ level of probability.

${ }^{+}$FW and DM : Fresh weight and Dry matter, respectively. ${ }^{++}$V1 and V2 : Morphoty 


\section{Data analyses}

Each analysis was replicated three times in a completely random design (CRD) according to the method of Steele and Torrie (1995). Means, where significantly different were separated using the least significant difference at 5\% level of probability. All the chemical analyses results were presented on fresh weight (FW) and dry weight (DW) basis to allow for proper comparison with the works of earlier authors, which were either presented as FW or DW.

\section{Results and Discussion}

The dry matter contents of the pulp of Morphotype I (V1) and Morphotype II (V2) were 10.9 and 9.6 $\mathrm{g} / 100 \mathrm{~g} \mathrm{FW}$, while the ascorbic acid contents were 25.7 and $24.8 \mathrm{mg} / 100 \mathrm{~g} \mathrm{FW}$, respectively (Table 1). These values are consistent with those reported by Adebooye et al. (2005) and Adebooye and Oloyede (2006) for the same morphotypes of $T$. cucumerina. The dry matter values are higher when compared with the dry matter contents of 8.3 $\mathrm{g} / 100 \mathrm{~g} \mathrm{FW}$ and $5.3 \mathrm{~g} / 100 \mathrm{~g} \mathrm{FW}$ reported for Aranca tomatoes and Excell tomatoes, respectively by Sahlin et al. (2004). The values obtained for ascorbic acid in this study are higher than those reported for Solanaceous tomato by Davey et al. (2000) (16 mg/100g FW) and Sahlin et al. (2004) (9.6 mg/100g FW for Excell Tomatoes). The ascorbic acid values are however comparable with 25.5-23.7 mg/100g FW reported for tomatoes by Burlingame et al. (1993) and Sahlin et al. (2004). Statistical analyses showed that there was no significant difference in the lycopene and total tannins contents of the two snake tomato morphotypes. The lycopene contents of the two morphotypes of $T$. cucumerina (18.0 and $16.1 \mathrm{mg} / 100 \mathrm{~g} \mathrm{FW})$ were within the range of values (5.2- $42.0 \mathrm{mg} / 100 \mathrm{~g}$ FW) reported for field-grown Solanaceous tomatoes by various workers including Gomez et al. (2001) and Takeoka et al. (2001).

The lycopene contents for T. cucumerina were however higher than 2.6-3.9 mg/100g FW reported for two Solanaceous tomato varieties by Sahlin et al. (2004). The total tannins contents of the two morphotypes of $T$. cucumerina were 27.3 and $25.0 \mathrm{mg} / 100 \mathrm{~g}$ FW. However, the total phenolics, total flavonoids and total anti-oxidant power (Table 1) of the two T. cucumerina morphotypes differ significantly $(\mathrm{P}<0.05)$. The total phenolics, total flavonoids and total (FRAP) anti-oxidant power of V2 were higher than that of V1 by $46.8 \%, 78.0 \%$ and $26.2 \%$, respectively. These differences could be attributed to genotype. Previous studies by Adebooye et al. (2005), Adebooye and Oloyede (2005) and Oloyede and Adebooye (2006) have shown clear genotypic differences between the two morphotypes of T. cucumerina. The higher FRAP obtained for V2 in this study could be attributed to its higher contents of phenolics and flavonoids compared to V1. High concentration of phenolics and flavonoids have been shown to command high free radical scavenging activity in plant (Zhang and Hamauzu, 2004; Sahlin et al., 2004). The values of phenolics for T. cucumerina are comparable to the values reported for tomato by Sahlin et al. (2004).

Literature survey revealed that, there is no report on the anti-oxidant composition and anti-oxidant power of T. cucumerina fruit pulp in literature. However, earlier study on another member of Cucurbitaceae (pumpkin) using the Trolox equivalent antioxidant capacity (TEAC) assay showed that this vegetable contains high level of carotenoids (Muller, 1997), especially less lipid-soluble carotenoids such as lutein, which had high antioxidant efficiency in the TEAC assay (Miller et al., 1996). The FRAP of the two morphotypes of T. cucumerina reported in this paper $\left(189.0\right.$ and $\left.270.4 \mathrm{mM} \mathrm{Fe}^{2+} / 100 \mathrm{~g} \mathrm{DM}\right)$ are higher than those that were reported for different melons that are also members of Cucurbitaceous family by Buratti et al. (2000), Halvorsen et al. (2002), Leong and Shui (2002) and Nicoletta et al. (2003).

Table 2 shows that the carotenoids components of the two morphotypes of $T$. cucumerina did not differ significantly. Results also showed that bulk of the carotenoids is made up of lutein (143.1-191.7 mg/100g DM) and V2 had significantly higher lutein content than V1. The different values obtained for lutein, $\alpha$-carotene and $\beta$ carotene in this study fall within the 0.06 to $7.4 \mathrm{mg} / 100 \mathrm{~g}$ for $\alpha$-carotene, 0 to $7.5 \mathrm{mg} / 100 \mathrm{~g}$ for $\beta$-carotene and 0 to 17 $\mathrm{mg} / 100 \mathrm{~g}$ for lutein reported for pumpkin (Cucurbitaceae) by Murkovic et al. (2002). The high antioxidant power in T. cucumerina fruit pulp was suspected to be related to its high contents of lycopene, ascorbic acid, carotenoids, total flavonoids and phenolics because, earlier studies on fruits have shown that high antioxidant capacity is dependent on high content of phenolic acids, carotenoids, vitamin $\mathrm{C}$ and flavonoids such as anthocyanins (Halvorsen et al., 2002; Kähkönen et al. 1999; Kalt et al., 1999; Macheix et al.., 1999; Häkkinen et al., 1999 and Gorinstein et al., 2001 ).

It can be concluded from the results of this study that the two morphotypes of T. cucumerina possess valuable nutraceutical properties that man must take advantage of. The fruit pulp contains ascorbic acid, lycopene, phenolics, flavonoids and antioxidant power that are comparable to that of Solanaceous tomato and are higher than those of most widely eaten members of Cucurbitaceae. 


\section{Acknowledgements}

Dr Adebooye is grateful to the United Nations University (UNU), Tokyo, Japan and the Council for Scientific and Industrial Research (CSIR), India for providing the joint funding and resources for this project.

\section{References}

1. Abukutsa-Onyago, M. A. (2003). The role of African indigenous vegetables in poverty alleviation in Kenya. Proc. of the 1st PROTA Int. Workshop 23-25, September, 2002, Nairobi, Kenya. pp. 269-270.

2. Adebooye, O.C. (1996) Proximate composition and nutrient analysis of six selected leaf vegetables of southwest Nigeria. Ife J. Agric. 18: 56-62.

3. Adebooye, O.C., Ogbe, F.M.D. and J.F. Bamidele (2001). Ethnobotanical Studies and Utilization of the Indigenous Leaf Vegetables of Southwest Nigeria. Technical Report. 64 p. Accra, Ghana: United Nations University/Institute for Natural Resources in Africa.

4. Adebooye, O. C., F. M. Oloyede, J. T. Opabode and O. O. Onagoruwa (2005). Fruit characteristics and nutrient composition of landrace morphotypes of Snake Tomato. J. Vegetable Sci. 11(4): 5-16.

5. Adebooye, O.C. and F.M. Oloyede. 2006. Responses of fruit yield and Quality of Trichosanthes cucumerina landraces to phosphorus rate. J. Vegetable Sci. 12 (1) : 5-19

6. Amin, I., Zamaliah, M.M. and W.F. Chin. 2004. Total antioxidant activity and phenolic content in selected vegetables. Food Chem. 87: 581-586.

7. Benzie, I.F. and J.J. Strain (1996). The ferric reducing ability of plasma as a measure of "antioxidant power" the FRAP assay. Analy. Biochem. 239: 70-76.

8. Buratti, S., Pellegrini, N., Brenna, O. V. and S. Mannino (2001). Rapid electrochemical method for the evaluation of the antioxidant power of some lipophilic food extracts. J. Agric. Food Chem. 49:5136-5141.

9. Burlingame, B.A., Milligan, G.C., Apimerika, D.E. and J.M. Arthur (1993). The concise New Zealand Food Composition Tables. New Zealand Institute for Crop and Food Research and the Department of Health, Wellington, NZ.

10. Cao, G., Sofic, E., and R. L. Prior (1996). Antioxidant capacity of tea and common vegetables. J. Agric. Food Chem. 44: 3426-3431.

11. Chweya, J. (1996). Genetic enhancement of indigenous vegetables in Kenya. In L.Guarino (Ed). Traditional Afr. Veg. Proc. of the IPGRI Int. Workshop on Traditional Afr. Veg. Conservation and Use. August 29- 31, 1995, Nairobi, Kenya. pp. 86-95.

12. Cohen, J. H., Kristal, A. R., and J. L. Stanford. (2000). Fruit and vegetable intakes and prostate cancer risk. J. Nat. Cancer Inst. 92: 61-68.

13. Davey, M.W., Van Montagu, M., Inze, D., Sanmartin, M., Kanellis, A., Smirnoff, N., Benzie, I.J.J., Strain, J.J., D. Favell, and J. Fletcher. (2000). Plant 1-ascorbic acid: chemistry, function, metabolism, bioavailability, and effects of processing. J. Sci. Food Agric. 80: 825-860.

14. FAO. (1998). The global plan of action on plant genetic resources for food and agriculture. Rome, Italy. pp. 104.

15. Gomez, R., Costa, J., Amo, M., Alvarruiz, A., Picazo, M., Pardo, J.E. (2001). Physicochemical and colorimetric evaluation of local varieties of tomato grown in SE Spain. J. Sci. Food Agric. 81: 1101-1105.

16. Gorinstein, S., Martin-Belloso, O., Park, Y. S., Haruenkit, R., Lojek, A., Ciz, M., Caspi, A., Libman, I. and S. Trakhtenberg (2001). Comparison of some biochemical characteristics of different citrus fruits. Food Chem. 74:309-315.

17. Häkkinen, S., Heinonen, M., Karenlampi, S., Mykkanen, H., Ruuskanen, J. and R. Torronen (1999). Screening of selected flavonoids and phenolic acids in 19 berries. Food Res. Intern. 32:345-353.

18. Halvorsen, B. L., Holte, K., Myhrstad, M.C.W., Barikmo, I., Hvattum, E., Fagertun Remberg, S., Wold, A. B., Haffner, K., Baugerod, H., Frost Andersen, L., Moskaug, J. O., Jacobs, D. R. and R. Blomhoff (2002). A systematic screening of total antioxidants in dietary plants. J. Nutrit. 132:461-471.

19. Howard, L. R., Talcott, S. T., Brenes, C. H. and B. Villalon (2000). Changes in phytochemical and antioxidant activity of selected pepper cultivars (Capsicum species) as influenced by maturity. J. Agric. Food Chem. 48: 1713-1720.

20. Kähkönen, M. P., A. I. Hopia, H. J. Vuorela, J. P. Rauha, K. Pihlaja, T. S. Kujala and M. Heinonen. (1999). Antioxidant activity of plant extracts containing phenolic compounds. J. Agric. Food Chem. 47:3954-3962 
21. Kalt, W., C. F. Forney, A. Martin and R. L. Prior (1999). Antioxidant capacity, vitamin C, phenolics, and anthocyanins after fresh storage of small fruits. J. Agric. Food Chem. 47:4638-4644

22. Knekt, P., J. Kumpulainen, R. Jarvinen, H. Rissanen, M. Heliovaara, A. Reunanen, T. Halulinen and A. Aromaa (2002). Flavonoids intake and risk of chronic diseases. Am. J. Clinical Nutrit. 76: 560-568.

23. Lavelli, V., Peri, C. and A. Rizzolo (2000). Antioxidant activity of tomato products as studied by model reactions using xanthine oxidase, myeloperoxidase, and copperinduced lipid peroxidation. J. Agric. Food Chem. 48: $1442-1448$.

24. Leong, L. P. and G. Shui (2002). An investigation of antioxidant capacity of fruits in Singapore markets. Food Chem. 76:69-75.

25. Liu, S., J. E. Manson, I. M. Lee, S. R.Cole, C. H. Hennekens, W. C. Willett, and J. Burning (2000). Fruit and vegetable intake and risk of cardiovascular disease: The Women_s Health Study. Am. J. Clinical Nutrit.: 72::922-928.

26. Macheix, J. J., Fleuriet, A. and J. Billot (1990). Fruit Phenolics 1990 CRC Press Boca Raton, FL.

27. Marinova, D., F. Ribarova and M. Atanassova (2005). Total phenolics and total flavonoids in Bulgarian fruits and vegetables. J Univ. Chem. Technol. Metallurgy 40: 255-260.

28. Miller, N. J., J. Sampson, L. P. Candeias, P. M. Bramley, and C. A. Rice-Evans. 1996. Antioxidant activities of carotenes and xanthophylls. FEBS Lett. 384:240-242

29. Mizda, Y., H. Shinmoto, M. Kobori, and T. Tsushida. 2002. Separation and quantification of carotenoids and chlorophylls in vegetables by high-performance liquid chromatography. J. Japanese Soc. Food Sci. Technol., 49(7): $500-506$.

30. Muller, H. (1997). Determination of the carotenoid content in selected vegetables and fruit by HPLC and photodiode array detection. Z. Lebensm. Unters. Forsch. 204:88-94.

31. Murkovic M.; Mülleder U. and H. Neunteufl (2002). Carotenoid content in different varieties of pumpkins. J. Food Comp. Analy. 15: 633-638

32. Nicoletta P., M. Serafini, B. Colombi, D. Del Rio, S. Salvatore, M. Bianchi and F. Brighenti (2003). Total Antioxidant Capacity of Plant Foods, Beverages and Oils Consumed in Italy Assessed by Three Different In Vitro Assays. J. Nutrit. 133:2812-2819

33. Oloyede, F.M. and O. C. Adebooye (2005). Effect of season on growth, fruit yield and nutrient profile of two landraces of Trichosanthes cucumerina L. Afr. J. Biotech. 4(6): 1040-1044

34. Pearson, D. (1976). The Chemical Analysis of Foods, 7th edn. 572 p. London: Churchill Livingstone.

35. Sahlin E, G.P. Savage and C.E Lister (2004). Investigation of the antioxidant properties of tomatoes after processing. J. Food Comp. Analy. 17: 635-647

36. Steele, S. G. D. and J. H. Torrie (1995). Principles and procedures of statistics. McGraw-Hill Book Company Inc., New York.

37. Sweeney, M. I., Kalt, W., Mackinnon, S. L., Ashby, J., and K. T. Gottschall- Pass (2002). Feeding rats diets enriched in lowbush blueberries for six weeks decreases ischemia-induced brain damage. Nutrit. Neuroscience 5(6): $427-431$.

38. Van het Hof, K.H., B.C.J. De Boer, L.B.M. Tijburg, B.R.H.M. Lucius, I. Zijp, C.E. West, J.G.A.J. Hautvastand J.A. Weststrate (2000). Carotenoid bioavailability in humans from tomatoes processed in different ways determined from the carotenoid response in the triglyceride-rich lipoprotein fraction of plasma after a single consumption and in plasma after four days of consumption. J. Nutrit. 130: 1189-1196.

39. Velioglu, Y. S., G. Mazza, L. Gao, and B. D. Oomah (1998). Antioxidant activity and total phenolics in selected fruits, vegetables, and grain products. J. Agri. Food Chem. 46: 4113-4117.

40. Wang, H., Cao, G. and R. L. Prior. (1996). Total antioxidant capacity of fruits. J. Agric Food Chem. 44: 701705 .

41. Zhang D and Y. Hamauzu (2004). Phenolics, ascorbic acid, carotenoids and antioxidant acvtivity of broccoli and their changes during conventional and microwave cooking. Food Chem. 88: 503-509. 